\title{
A Possibility to Improve the Onion (Allium Cepa L.) Culture Technology by Direct Sowing
}

\author{
Alexandru-Dan CĂPRARIU*), Maria APAHIDEAN and Alexandru I. APAHIDEAN \\ Department of Horticulture and Landscape Design, University of Agricultural Sciences and Veterinary \\ Medicine, Cluj-Napoca, Romania \\ *)corresponding author, e-mail: alexandru.caprariu@gmail.com
}

BulletinUASVM Horticulture 72(1) / 2015

Print ISSN 1843-5254, Electronic ISSN 1843-5394

DOI:10.15835/buasvmcn-hort:10559

\begin{abstract}
The paper presents the results obtained after performing studies in the north-west part of the country, on two varieties of onion: Density 4 and Ramata rossa di Milano, direct seeded in two epochs at two densities of $2 \mathrm{~cm}$ and $4 \mathrm{~cm}$ between plants and $25 \mathrm{~cm}$ between rows. The majority of the plants obtained by direct sowing in autumn epoch issued floriferous stems and the culture was compromised in terms of production of bulbs. Plants obtained by direct sowing in spring epoch in both varieties and seeding densities normally developed, yielding an average of $54.12 \mathrm{t} / \mathrm{ha}$ for Density 4 to a density of 1 million $\mathrm{pl} / \mathrm{ha}$, and $51.31 \mathrm{t} / \mathrm{ha}$ at a density of 2 million $\mathrm{pl} / \mathrm{ha}$. Ramata Rossa di Milano obtained an average yield of 51,07 t/ha at a density of 1 million pl/ha and $58.38 \mathrm{t} / \mathrm{ha}$ at a density of 2 million $\mathrm{pl} / \mathrm{ha}$. Average production for the variety Density 4 to a density of 1 million $\mathrm{pl} / \mathrm{ha}$ is higher than the average production at a density of 2 million pl/ha. Ramata rossa di Milano variety, at a density of $2 \mathrm{million} \mathrm{pl} / \mathrm{ha}$, the average yield was higher than average production at a density of 1 million $\mathrm{pl} / \mathrm{ha}$.
\end{abstract}

Keywords: direct sowing, onion-yield, onion variety, plant density

\section{INTRODUCTION}

The desire to obtain higher yields, led to the improvement and development of agrotechnical measures that can modify and influence environmental conditions so as to ensure optimal conditions for plant growth. It is mandatory for the grower to know the environmental natural conditions of the area where they.

Continuous population growth requests obtaining greater and higher quality crops yields. In the measures that may lead to increased agricultural production, particularly important are those which refers to introduction aside unproductive land and increase production per a surface unit. Solving these problems is based primarily on knowing how important soil is for agricultural production (Blaga et al., 2005).

The share of vegetable consumption in human nutrition has been growing and healthy eating have to include vegetables and fruits. Recently, we have seen that the standard of living is measured in the amount of vegetables that you consume (Bayer CropScience, 2014).

Onion is a profitable crop in terms of achieving a normal production. To achieve profitable crops of onions requires a certain level of production, which is estimated at $15-20 \mathrm{t} / \mathrm{ha}$ for direct sown onions and 20-25 t/ha of seedling onions. (Apahidean, 2009; Ciofu, 2003; Dina, 1979). It is generally estimated that by direct sowing the production costs are with 32\% lower than the other methods of culture (Butnariu et al., 1992).

Popandron conducted a study in 2007 that showed that onion production is strongly influenced by used variety. Thus in this study were taken into consideration 15 varieties of onions. Production ranged from $82 \mathrm{t} / \mathrm{ha}$ to $54 \mathrm{t} / \mathrm{h}$. 
The yields obtained in another study conducted in southern Italy by Caruso in 20102011 and co-workers was between 44.3 t/ha and $60.0 \mathrm{t} / \mathrm{ha}$. The yields obtained ranged due to planting date and sowing density.

The general recommendations on plant density for onion are very different, depending by the author and experimental conditions. Some authors recommend that the minimum density of onion plants, to ensure normal production should be between 35-40 plants/ mp (Bălaşa, 1973). Krug et al. (1986), Chaux and Foury (1995), recommend densities up to 150 plants/ $\mathrm{mp}$ for common varieties and 80-100 and plants $/ \mathrm{mp}$ for hybrids. Apahidean et al. (1996) after conducting a study on the onion culture, concluded that at an optimal water supply, the increasing plant density from 50 to 80 plants $/ \mathrm{mp}$ led to a yield increase of $13.3 \%$ at Wolski variety and of $24.0 \%$ at the variety Red of Turda.

\section{MATERIALS AND METHODS}

In this research, two onion cultivars were used as biological material, the variety Density 4 and Ramata Rossa di Milano variety. Density 4 , tardy variety with good resistance to drought and storage. The bulb is large, slightly elongated spherical, sharp to the top, golden colour, sweet taste, slightly spicy. The storage capacity and onion mildew (Peronospora destructor) resistance is also very good. It is suitable for fresh consumption, for storage, in food industry and for obtaining culinary spices (Figure 1).

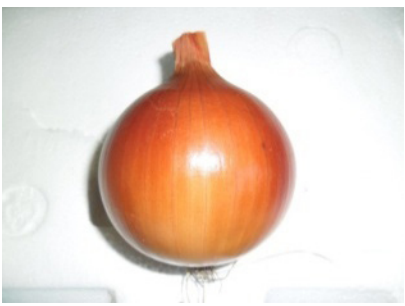

Fig.1.Density 4 variety bulb.

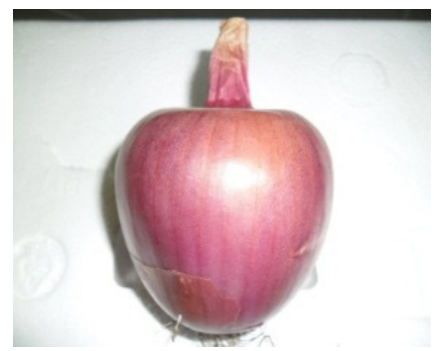

Fig.2.Ramata Rossa di Milano variety bulb. (source: Căprariu, 2013, Gherla)
Ramata Rossa di Milano, tardy variety, productive, with vigorous growth, large bulbs, elongated, tapering backwards, crimson red color both outside and inside. Storage capacity is very good being suitable for fresh consumption and storage (Figure 2).

Regarding the method of work to achieve the research objectives, comparative experiments in the field were organized, which were polifactorial. The focus was on three factors: variety, sowing time and plant density, each with two graduations.

\section{Factor A - variety \\ a1 - Density 4; \\ a2 - Ramata Rossa di Milano;}

\section{Factor B - sowing time}

b1 - Spring epoch (February - March);

b2 - Autumn epoch (August - September);

\section{Factor C - plant density}

c1 - 1 million pl./ha;

c2 - 2 million pl./ha.

From the combination of experimental factors resulted eight experimental variants located in subdivided blocks, each variant had 3 repetitions (Table 1).

Total surface of experimental plots, is $14 \mathrm{sqm}$ with a length of $10 \mathrm{~m}$ and a width of $1.4 \mathrm{~m}$, and the whole experience occupied an area of $336 \mathrm{sqm}$.

The average amounts of seeds used were 4 $\mathrm{kg} / \mathrm{ha}$ to a density of 1 million $\mathrm{pl} / \mathrm{ha}$ and $8 \mathrm{~kg} / \mathrm{ha}$ to 2 million $\mathrm{pl} / \mathrm{ha}$.

The plant density was achieved by weeding out when the plants had 2-3 leaves.

The experiment was conducted in Gherla town which is located in northwest Transylvania Plateau, on the Someșul Mic River, at the contact area between the Transylvanian Plain and Someş Plateau approximately at $47^{\circ} \mathrm{N}$ and $24^{\circ} \mathrm{NE}$.

Gherla town has a temperate climate influenced by the hills that are nearby and without a big influence of the oceanic air masses. The average annual rainfall in the Carpathian foothills of the plateau varies between 600 and $700 \mathrm{~mm}$.

The soil where were placed the experiences, is loam-clay with high humus content, poor alkaline reaction, very favourable for vegetable crops.

The thermal regime is characterized by average annual temperatures around $8^{\circ} \mathrm{C}$. Early 
frosts were reported in mild-September (17.IX.) and the latter frosts at the end of April (22.III.). Average duration without frosty temperatures is 180 days.

\section{RESULTS AND DISCUSSION}

In 2013 the average yield on experience was $37.76 \mathrm{t} / \mathrm{ha}$. Under the unilateral influence of variety of bulbs on production (Table 2), the variety Ramata Rossa di Milano recorded a production increase of $4.39 \mathrm{t} / \mathrm{ha}$, significantly distinct versus variety Density 4 , considered control. If the average experience is considered control, the difference recorded by the two varieties is $2.20 \mathrm{t} / \mathrm{ha}$, positive for Ramata Rossa di Milano and negative for Density 4. Difference in statistically significant.

The variants sown in autumn obtained a much lower yield than the ones sown in spring. The spring epoch obtained an average yield of 53.72 t/ha and the autumn epoch registered an average yield of $21.80 \mathrm{t} / \mathrm{ha}$. The difference obtained was of $31.92 \mathrm{t} / \mathrm{ha}$, that shows that the autumn culture was compromised. The main cause of low yield obtained is the very high percentage of plants that formed floriferous stems (Table 3).

Tab. 1. Experimental variant at Gherla, 2013-2015

\begin{tabular}{|lllc|}
\hline Variant & Variety & Sowing time & Density (million pl/ha) \\
\hline V1-a1b1c1 & Density 4 & Spring epoch & 1 \\
\hline V2-a1b1c2 & Density 4 & Spring epoch & 2 \\
\hline V3-a1b2c1 & Density 4 & Autumn epoch & 1 \\
\hline V4-a1b2c2 & Density 4 & Autumn epoch & 2 \\
\hline V5-a2b1c1 & Ramata rossa di Milano & Spring epoch & 1 \\
\hline V6-a2b1c2 & Ramata rossa di Milano & Spring epoch & 2 \\
\hline V7-a2b2c1 & Ramata rossa di Milano & Autumn epoch & 1 \\
\hline V8-a2b2c2 & Ramatarossa di Milano & Autumnepoch & 2 \\
\hline
\end{tabular}

Tab. 2.Unilateral influence of the onion variety on the obtained yield at Gherla, 2013

\begin{tabular}{|c|c|c|c|c|c|c|c|}
\hline \multirow{2}{*}{$\begin{array}{l}\text { Variant } \\
\text { Variety }\end{array}$} & \multicolumn{2}{|c|}{ Average yield } & \multirow{2}{*}{$\begin{array}{c}\text { Differences } \\
\text { t/ha }\end{array}$} & \multirow{2}{*}{ Significance } & \multirow{2}{*}{$\begin{array}{c}\text { Relative yield } \\
(\%)\end{array}$} & \multirow{2}{*}{$\begin{array}{c}\text { Differences } \\
\text { t/ha }\end{array}$} & \multirow{2}{*}{$\begin{array}{l}\text { Signifi- } \\
\text { cance }\end{array}$} \\
\hline & t/ha & $\%$ & & & & & \\
\hline Density 4 (Mt.) & 35.57 & 100.0 & - & - & 94.2 & -2.20 & 0 \\
\hline $\begin{array}{l}\text { Ramata rossa di } \\
\text { Milano }\end{array}$ & 39.96 & 112.3 & 4.39 & $* *$ & 105.8 & 2.20 & $*$ \\
\hline Average (Mt.) & 37.76 & - & - & - & 100.0 & - & - \\
\hline \multicolumn{3}{|l|}{$\mathrm{DL} / L S D(\mathrm{p} 5 \%)$} & \multicolumn{2}{|l|}{1.39} & \multicolumn{3}{|c|}{1.39} \\
\hline \multicolumn{3}{|l|}{$\mathrm{DL} / L S D(\mathrm{p} 1 \%)$} & \multicolumn{2}{|l|}{3.20} & \multicolumn{3}{|c|}{3.20} \\
\hline \multicolumn{3}{|l|}{$\mathrm{DL} / L S D(\mathrm{p} 0,1 \%)$} & \multicolumn{2}{|l|}{10.19} & \multicolumn{3}{|c|}{10.19} \\
\hline
\end{tabular}

Tab. 3. Unilateral influence of the sowing time on the obtained yield at Gherla, 2013

\begin{tabular}{|c|c|c|c|c|c|c|c|}
\hline \multirow{2}{*}{\begin{tabular}{|l|} 
Variant \\
Sowing time \\
\end{tabular}} & \multicolumn{2}{|c|}{ Average yield } & \multirow{2}{*}{$\begin{array}{c}\text { Differences } \\
\text { t/ha }\end{array}$} & \multirow{2}{*}{ Significance } & \multirow{2}{*}{$\begin{array}{c}\text { Relative } \\
\text { yield (\%) }\end{array}$} & \multirow{2}{*}{$\begin{array}{c}\text { Differences } \\
\text { t/ha }\end{array}$} & \multirow{2}{*}{ Significance } \\
\hline & t/ha & $\%$ & & & & & \\
\hline Spring epoch (Mt.) & 53.72 & 100.0 & - & - & 142.3 & 15.96 & $* * *$ \\
\hline Autumn epoch & 21.80 & 40.6 & -31.92 & 000 & 57.7 & -15.96 & 000 \\
\hline Average (Mt.) & 37.76 & - & - & - & 100.0 & - & - \\
\hline \multicolumn{3}{|l|}{ DL/LSD (p 5\%) } & \multicolumn{2}{|l|}{0.35} & \multicolumn{3}{|c|}{0.35} \\
\hline \multicolumn{3}{|l|}{ DL/ LSD (p 1\%) } & \multicolumn{2}{|l|}{0.58} & \multicolumn{3}{|c|}{0.58} \\
\hline \multicolumn{3}{|l|}{ DL/ LSD (p 0,1\%) } & \multicolumn{2}{|l|}{1.09} & \multicolumn{3}{|c|}{1.09} \\
\hline
\end{tabular}


Analyzing the unilateral influence of plant density per unit area on the production of bulbs (Table 4), it can be observed that the experimental variants with higher density ( 2 million $\mathrm{pl} / \mathrm{ha}$ ) recorded a production increase, significantly distinct versus experimental variants with a density of 1 million plants/ha, (control) due to the higher number of bulbs per unit area, even if the average weight of the bulb was lower at the variants with a higher density.

The combined influence of the variety and the sowing date on bulbs yield (Table 5 ) shows that the highest level of yield, $54.73 \mathrm{t} / \mathrm{ha}$, was obtained by the variety Ramata Rossa di Milano sown in spring. The Density 4 yield was also higher in the spring, but lower in comparison with Ramata Rossa di Milano with 2.01 t/ha.

In autumn epoch, thanks to lower percentage of plants that have issued floriferous steam Ramata
Rossa di Milano obtained an yiled with 6.77 t/ha higher than the variant considered control.

The yields obtained in another study conducted in southern Italy by Caruso in 20102011 and co-workers was between 44.3 t/ha and $60.0 \mathrm{t} / \mathrm{ha}$. The yields obtained ranged due to planting date and sowing density.

An average for the entire experience, Density 4 recorded the highest yield at a density of 1 million plants/ha. The obtained difference was statistically assured like very significant (2.76 t/ha).

Ramata Rossa di Milano has achieved the highest level of yield at a density of 2 million plants/ha, with a highly-significant difference of 4.85 t/ha, (Table 6).

Bulbs production was favored by the increase of plant density only in spring epoch, which registered a growth of $4.1 \%$, (Table 7).

Tab. 4. Unilateral influence of the plant density on the obtained yield at Gherla, 2013

\begin{tabular}{|c|c|c|c|c|c|c|c|}
\hline \multirow{2}{*}{$\begin{array}{c}\text { Variant } \\
\text { Plant density } \\
\text { (million. pl/ha) }\end{array}$} & \multicolumn{2}{|c|}{ Average yield } & \multirow{2}{*}{$\begin{array}{c}\text { Differences } \\
\text { t/ha }\end{array}$} & \multirow[b]{2}{*}{ Significance } & \multirow{2}{*}{$\begin{array}{c}\text { Relative } \\
\text { yield (\%) }\end{array}$} & \multirow{2}{*}{$\begin{array}{c}\text { Differences } \\
\text { t/ha }\end{array}$} & \multirow[b]{2}{*}{ Significance } \\
\hline & t/ha & $\%$ & & & & & \\
\hline 1 (Mt.) & 37.24 & 100.0 & - & - & 98.6 & -0.52 & ns \\
\hline 2 & 38.28 & 102.8 & 1.04 & ** & 101.4 & 0.52 & ns \\
\hline Average (Mt.) & 37.76 & - & - & - & 100.0 & - & - \\
\hline DL/LSD (p 5\%) & & & 0.66 & & & 0.66 & \\
\hline DL/ LSD (p 1\%) & & & 0.97 & & & 0.97 & \\
\hline DL/ LSD (p $0,1 \%)$ & & & 1.45 & & & 1.45 & \\
\hline
\end{tabular}

Tab.5. The combined influence of the variety and the sowing time on the obtained yield at Gherla, 2013

\begin{tabular}{|c|c|c|c|c|c|c|c|c|}
\hline \multicolumn{2}{|c|}{ Experimental Variant } & \multicolumn{2}{|c|}{ Average yield } & \multirow{2}{*}{$\begin{array}{c}\text { Differen- } \\
\text { ces } \\
\text { t/ha } \\
\end{array}$} & \multirow{2}{*}{$\begin{array}{l}\text { Signifi- } \\
\text { cance }\end{array}$} & \multirow{2}{*}{$\begin{array}{c}\text { Relative } \\
\text { yield } \\
(\%)\end{array}$} & \multirow{2}{*}{$\begin{array}{c}\text { Differen- } \\
\text { ces } \\
\text { t/ha } \\
\end{array}$} & \multirow{2}{*}{$\begin{array}{l}\text { Signifi- } \\
\text { cance }\end{array}$} \\
\hline Variety & Sowing time & t/ha & $\%$ & & & & & \\
\hline Density 4 & Spring (Mt.) & 52.71 & 100.0 & - & - & 98.1 & -1.01 & ns \\
\hline $\begin{array}{c}\text { Ramata rossa } \\
\text { di Milano }\end{array}$ & Spring & 54.73 & 103.8 & 2.01 & $*$ & 101.9 & 1.01 & ns \\
\hline \multicolumn{2}{|c|}{ Average (Mt.) } & 53.72 & - & - & - & 100.0 & - & - \\
\hline Density 4 & Autumn (Mt.) & 18.42 & 100.0 & - & - & 84.5 & -3.39 & oо \\
\hline $\begin{array}{l}\text { Ramata rossa } \\
\text { di Milano }\end{array}$ & Autumn & 25.19 & 136.8 & 6.77 & $* *$ & 115.5 & 3.39 & ** \\
\hline \multicolumn{2}{|c|}{ Average (Mt.) } & 21.80 & - & - & - & 100.0 & - & - \\
\hline \multicolumn{2}{|c|}{$\mathrm{DL} / L S D(\mathrm{p} 5 \%)$} & & & 1.42 & & & 1.42 & \\
\hline \multicolumn{2}{|c|}{ DL/ LSD (p 1\%) } & & & 3.19 & & & 3.19 & \\
\hline \multicolumn{2}{|c|}{ DL/ LSD (p 0,1\%) } & & & 9.88 & & & 9.88 & \\
\hline
\end{tabular}


Tab.6. The combined influence of the variety and the plant density on the obtained yield at Gherla,2013

\begin{tabular}{|c|c|c|c|c|c|c|c|c|}
\hline \multicolumn{2}{|c|}{ Experimental Variant } & \multicolumn{2}{|c|}{ Average yield } & \multirow{2}{*}{$\begin{array}{c}\text { Differe- } \\
\text { ces } \\
\text { t/ha } \\
\end{array}$} & \multirow[b]{2}{*}{$\begin{array}{c}\text { Significan- } \\
\text { ce }\end{array}$} & \multirow{2}{*}{$\begin{array}{c}\text { Relative } \\
\text { yield } \\
(\%)\end{array}$} & \multirow{2}{*}{$\begin{array}{c}\text { Differen- } \\
\text { ces } \\
\text { t/ha } \\
\end{array}$} & \multirow[b]{2}{*}{$\begin{array}{c}\text { Significan- } \\
\text { ce }\end{array}$} \\
\hline Variety & $\begin{array}{c}\text { Plant } \\
\text { density }\end{array}$ & t/ha & $\%$ & & & & & \\
\hline Density 4 (Mt.) & 1 & 36.95 & 100.0 & - & - & 103.9 & 1.38 & $* *$ \\
\hline Density 4 & 2 & 34.18 & 92.5 & -2.76 & 000 & 96.1 & -1.38 & oo \\
\hline Average (Mt.) & & 35.57 & - & - & - & 100.0 & & \\
\hline $\begin{array}{l}\text { Ramata rossa di } \\
\text { Milano (Mt.) }\end{array}$ & 1 & 37.53 & 100.0 & - & - & 93.9 & -2.42 & 000 \\
\hline $\begin{array}{l}\text { Ramata rossa di } \\
\text { Milano }\end{array}$ & 2 & 42.38 & 112.9 & 4.85 & $* * *$ & 106.1 & 2.42 & $* * *$ \\
\hline Average (Mt.) & & 39.96 & - & - & - & 100.0 & - & - \\
\hline $\mathrm{DL} / L S D(\mathrm{p} 5 \%)$ & & & & 0.94 & & & 0.94 & \\
\hline DL/ LSD (p 1\%) & & & & 1.37 & & & 1.37 & \\
\hline $\mathrm{DL} / L S D(\mathrm{p} 0,1 \%)$ & & & & 2.05 & & & 2.05 & \\
\hline
\end{tabular}

Tab. 7. The combined influence of the plant density and the sowing date on the obtained yield Gherla, 2013

\begin{tabular}{|c|c|c|c|c|c|c|c|c|}
\hline \multicolumn{2}{|c|}{ Experimental Variant } & \multicolumn{2}{|c|}{ Average yield } & \multirow{2}{*}{$\begin{array}{c}\text { Differen- } \\
\text { ces } \\
\text { t/ha }\end{array}$} & \multirow[b]{2}{*}{ Significance } & \multirow{2}{*}{$\begin{array}{c}\text { Relative } \\
\text { yield } \\
(\%)\end{array}$} & \multirow{2}{*}{$\begin{array}{c}\text { Differen- } \\
\text { ces } \\
\text { t/ha }\end{array}$} & \multirow[b]{2}{*}{ Significance } \\
\hline $\begin{array}{c}\text { Plant } \\
\text { density }\end{array}$ & $\begin{array}{c}\text { Sowing } \\
\text { time }\end{array}$ & t/ha & $\%$ & & & & & \\
\hline 1 & $\begin{array}{l}\text { Spring } \\
\text { (Mt.) }\end{array}$ & 52.59 & 100.0 & - & - & 97.9 & -1.13 & 0 \\
\hline 2 & Spring & 54.85 & 104.3 & 2.25 & $* * *$ & 102.1 & 1.13 & $*$ \\
\hline \multicolumn{2}{|c|}{ Average (Mt.) } & 53.72 & - & - & - & 100.0 & - & - \\
\hline 1 & $\begin{array}{l}\text { Autumn } \\
\text { (Mt.) }\end{array}$ & 21.89 & 100.0 & - & - & 100.4 & 0.08 & ns \\
\hline 2 & Autumn & 21.72 & 99.2 & -0.17 & ns & 99.6 & -0.08 & ns \\
\hline \multicolumn{2}{|c|}{ Average (Mt.) } & 21.80 & - & - & - & 100.0 & - & - \\
\hline \multicolumn{2}{|c|}{$\mathrm{DL} / L S D(\mathrm{p} 5 \%)$} & & & 0.94 & & & 0.94 & \\
\hline \multicolumn{2}{|c|}{$\mathrm{DL} / L S D(\mathrm{p} 1 \%)$} & & & 1.37 & & & 1.37 & \\
\hline \multicolumn{2}{|c|}{$\mathrm{DL} / L S D(\mathrm{p} 0,1 \%)$} & & & 2.05 & & & 2.05 & \\
\hline
\end{tabular}

Tab. 8. The combined influence of the experimental factors on the obtained yield at Gherla, 2013

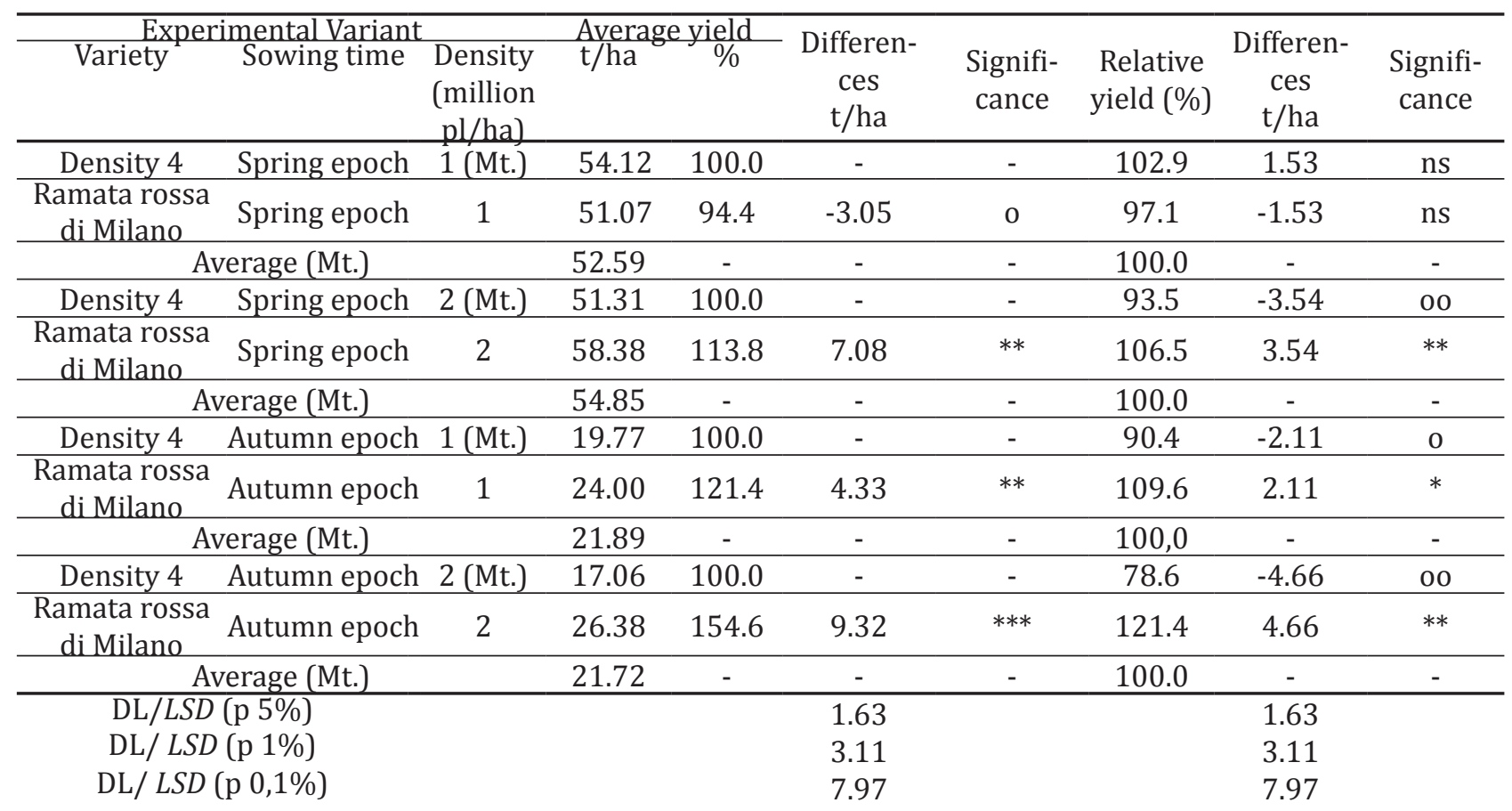


Under the combined influence of the three experimental factors (Table 8), the highest production was obtained by Ramata Rossa di Milano in spring epoch, at a density of 2 million plants/ha. The obtained yield was of $58.38 \mathrm{t} / \mathrm{ha}$, with a difference of $4.26 \mathrm{t} / \mathrm{ha}$ comparing it with the control. The difference was statistically assured as distinctly significant.

The yield obtained at the variant sown in autumn, was much lower than the ones sown in spring. Comparing the yields obtained by the variants, it can be observed that Ramata Rossa di Milano, at a higher density, registered the highest production.

\section{CONCLUSIONS}

Plants obtained by direct sowing in the autumn epoch have issued floriferous steam, both cultivars, and both sowing densities, so the culture was compromised in terms of production of bulbs. Plants obtained by direct sowing in spring epoch in both varieties and sowing densities were normally developed, yielding an average of $54.12 \mathrm{t} / \mathrm{ha}$ for variety Density 4 , to a density of 1 million $\mathrm{pl} / \mathrm{ha}$, and $51.31 \mathrm{t} / \mathrm{ha}$ at a density of 2 million plants/ha. The variety Ramata Rossa di Milano obtained an average yield of $51.07 \mathrm{t} / \mathrm{ha}$ at a density of 1 million plants/ha and $58.38 \mathrm{t} / \mathrm{ha}$ at a density of 2 milion plants/ha. The highest percentage of first quality of the yield was at varieties, Density 4 and Ramata Rossa di Milano, sown in spring epoch at a density of 1 million pl/ha.

Acknowledgements. This paper was published under the frame of European Social Fund, Human Resources Development Operational Programme
2007-2013, project no. POSDRU/159/1.5/S /132765.

\section{REFERENCES}

1. Indrea D, Apahidean Al S, Apahidean M, Maniutiu ND, Sima R (2009). Vegetables growing p.376, Ed. Ceres, Bucharest.

2. Apahidean Al S (1996). Researches concerning the water consuption and irrigation regim of onion and cabbage crops sown directily in the open field, in the pedoclimatic condition of the Transylvanian plateau PhD thesis, Cluj-Napoca.

3. Bălaşa M (1973). Vegetables Growing. E. D. P., Bucharest.

4. Blaga G, Filipov F, Udrescu S, Rusu I, Vasile D (2005). Pedology, Editura AcademicPres, Cluj-Napoca.

5. Butnariu H, Indrea D, Petrescu C, Savițchi P, Chilom P, Ciofu R, Popescu V, Radu Gr, Stan N (1992), Vegetables Growing, EDP, Bucharest.

6. Chaux CL and Foury CL (1995). Production legumieres, I-II. Ed TEC-DOC, Paris.

7. Ciofu R, Stan N, Popescu V, Chilom P, Apahidean Al S, Berar V, Horgoş A, Flauer KF, Atanasiu N.(2003). Vegetables Growing Treaty, Ed. Ceres, Bucharest.

8. Indrea et al. (1979). Vegetables Growing, EDP, Bucharest.

9. Gianluca C, Contia S, Villarib G, Borrellia C, Melchionnaa G, Minutoloa M, Russoa G, Amalfitano C (2014). Effects of transplanting time and plant density on yield, quality andantioxidant content of onion (Allium cepa L.) in southern Italy, Scientia Horticulturae 166:111-120.

10. Krug H et al. (1986). Gemüseproduktion. Paul Parey, Berlin-Hamburg.

11. Popandron N, Tudora M, Basturea M, Cernahoschi A (2010). The study of three factors that influence the onion production, Bulletin of USAMV Timişoara, Journal of Horticulture and Forestry 14(1):177-182.

12. ${ }^{* * *}$ Bayer CropScience (2014). Success in horticultural crops today and tomorrow. Ed. S.C. Bayer SRL Bucharest. 